\title{
THE PLASMA LEVELS OF VITAMINS A, E AND CAROTENE IN COWS IN LATE PREGNANCY AND IN THEIR FOETUSES
}

\author{
P. JAGOŠ, J. BOUDA and J. GERYK
} Department of Diagnosis, Therapy and Prophylaxis of Animal Diseases, University of Veterinary
Science, 61242 Brno

Received fanuary 22, 1979

\begin{abstract}
Jagoš P., J. Bouda, J. Geryk: The Plasma Levels of Vitamin A, E and Carotene in Cows in Late Pregnancy and in Their Foetuses. Acta vet. Brno, 48, 1979: 19-23.

Experiments involving 20 cows in late pregnancy and their foteuses aged 8-9 months were conducted to study the blood plasma content of the vitamins A, E and carotene and the liver vitamin A content of these individuals.

The vitamin A content of the foetal plasma was more than two times lower than that of the dams, and the foetal liver content of vitamin A was approximately ten times lower than the values found in the dams.

Similarly, much lower plasma content of vitamin $\mathrm{E}$ and carotene were determined in the foetuses than in their mothers. These differences were statistically significant.

The results of the study indicated that the bovine foetus and newborn calf have only minimum stores of the above-mentioned vitamins and they depend on early and abundant feeding of colostrum to meet their requirements.
\end{abstract}

Blood plasma, liver, mother, foetus, vitamins $A, E$.

An important part in the frequent calf diseases occurring predominantly in winter and spring is ascribed to the noninfectious factors including hypovitaminosis A. Decreased resistance of the organism and frequent diseases of the newborn animals have been known to result from the hypovitaminosis A (Moore 1957; Dvořák 1959, 1960; Přibyl 1963; Spratling et al. 1965; Seawright 1966; Rosenberger 1970; Radominski et al. 1970; Eaton et al. 1972). Calves are born with low plasma levels and stores of vitamin A and carotene which indicates a low transfer of these substances through the placenta (Moore 1957). Low vitamin A content was also found in the livers of bovine and equine foetuses (Harms 1951). The livers of bovine foetuses contained $1.5 \%$ of the amount of vitamin $A$ found in the livers of adult cattle. Somewhat higher percentage $-4 \%$ - was found in equine foetuses.

A certain amount of vitamin $A$ is necessary for the normal development of the foetus and its reserve of this vitamin during the first hours of postnatal life is important for survival and health of the newborn calf in the early postnatal period (Brantstetter et al. 1973). This follows from the observation of deaths in calves fed no colostrum which had extremely low vitamin A reserves (Moore 1957). In livers of 6 newborn calves an average of $7.3 \mu \mathrm{g}$ of vitamin A per $1 \mathrm{~g}$ liver tissue was found while in their mothers 37 times higher content was detected (Brantstetter et al. 1973). Similar vitamin A amounts were also found in bovine foetuses aged 110-240 days (Baetze and Hubert 1974). Nevertheless, in the blood serum of these foetuses $19.9 \mu \mathrm{g}$ per $100 \mathrm{ml}$ of vitamin A were found; this value is in good agreement with findings of Baker et al. (1953) and Spielman et al. (1946).

Good performance of young calves requires also vitamin E supporting mainly the muscular function (Kursa et al. 1969; Jenkins, Hidiroglou 1972; Vrzgula et al. 1972; Lannek 1973; Kováč et al. 1974). Its antioxidative properties enhance the utilization of vitamin A up to 6 times (Ames 1969).

The aim of the present work was to investigate the levels of vitamins $A, E$ and carotene in the plasma and livers of bovine foetuses and their mothers with possible practical use of the findings in diagnosing and prevention of hypovitaminoses in the newborn and young calves. 


\section{Materials and Methods}

For experiments, 20 healthy cows in late pregnancy and their 8-9 months old foetuses were employed. The average body mass of the foetuses was $32.1 \mathrm{~kg}$, ranging from 24.5 to $41.3 \mathrm{~kg}$. The foetuses were extracted by Caesarean section at the Department of Reproduction and Surgery of Farm Animals in order to obtain the foetal sera. Blood samples were collected from v. jugularis of the dams and from a. carotis of the foetuses. Tissue samples were collected from the right liver lobe of the animals.

The plasma levels of vitamins A and E were measured fluorometrically using the Spektrofluorometer Perkin-Elmer 204 by the method of Thompson et al. $(1971,1973)$ and Van Steveninck and De Goeij (1973) modified in the laboratory of our Department (Bouda, Jagoš 1979).

The liver content of vitamin A was measured flurometrically by the method of Thompson et al. (1971). The carotene content of blood plasma was determined fotometrically (Knobloch 1956).

\section{Results}

The average values of vitamins $\mathrm{A}$ and $\mathrm{E}$ carotene in the blood plasma and those of vitamin A in livers of the experimental cows and their foetuses are given in Table 1.

Table 1

Vitamins $A$ and $E$, and carotene in 20 bovine foetuses and their mothers

\begin{tabular}{|c|c|c|c|c|}
\hline Material & Parameter under study & Foetus & Mother & $\begin{array}{c}\text { Significance } \\
\text { of } \\
\text { differences }\end{array}$ \\
\hline Plasma & $\begin{array}{l}\operatorname{vitamin} A(\mu \mathrm{g} / 100 \mathrm{ml}) \\
\text { vitamin } \mathrm{E}(\mu \mathrm{g} / 100 \mathrm{ml}) \\
\text { carotene }(\mu \mathrm{g} / 100 \mathrm{ml})\end{array}$ & $\begin{array}{l}12.3 \pm 2.8 \\
97.2 \pm 69.0 \\
12.2 \pm 10.0\end{array}$ & $\begin{aligned} 27.8 & \pm 7.9 \\
339.0 & \pm 93.0 \\
353.3 & \pm 114.0\end{aligned}$ & $\begin{array}{l}++ \\
++ \\
++\end{array}$ \\
\hline Liver & $\operatorname{vitamin} \mathrm{A}(\boldsymbol{\mu g} / \mathbf{1} \mathbf{g})$ & $4.1 \pm 2.3$ & $40.2 \pm 9.5$ & $+t$ \\
\hline
\end{tabular}

$++=P 0.01$

Our results show that the plasma level of vitamin $\mathrm{A}$ in foetuses did not reach half the values determined in their mothers. Moreover, very low vitamin A content was found in foetal livers amounting some $10 \%$ of the values found in their mothers when expressed per $1 \mathrm{~g}$ of liver tissue. Extremely low vitamin E and carotene concentration were found in blood plasma of the foetuses as compared to that of their dams.

\section{Discussion}

The foetus and the newborn calf has no sufficient stores of vitamin A (Baetz and Hubert 1974; Harms 1951; Radostits and Bell 1970; Steinbach et al. 1970; Brantstetter et al. 1973). Early feeding of abundant amount of colostrum immediately after birth provides a good supply of vitamins as the colostrum contains much more vitamin A than the milk or plasma of the dam (Steinbach and Mayer 1967; Brantstetter et al. 1973; Jagoš et al. 1977).

The present study was made in winter and the carotene concentration in the plasma of the cows was accordingly lower but still exceeded by some 30 times the values found in their foetuses. The results indicate that the mean plasma level of vitamin A in the dams was high enough (Sebrell and Harris 1967; Rosen- 
berger 1970) but in several animals it was as low as $25 \mu \mathrm{g} / 100 \mathrm{ml}$ and even lower than $20 \mu \mathrm{g} / 100 \mathrm{ml}$. The average vitamin A amount in livers of our experimental cows was lower and extremely low in animals with the minimum plasma levels of the vitamin. The liver content of vitamin A in cows should not decrease below $50 \mu \mathrm{g} / 1 \mathrm{~g}$ liver tissue according to Rosenberger (1970). Schulz and Rossow (1975) consider the amount of vitamin A of 200 to $340 \mathrm{i}$. u./1 g liver tissue as physiological for cows. No direct relation between the low vitamin A levels in foetal and maternal livers can be found in the present experiment. Vitamin A amounted $27-56 \mu \mathrm{g} / 1 \mathrm{~g}$ of liver tissue in the dams.

Concentration of carotene in the blood plasma of the cows was rather low but still about 30 times higher than in the plasma of their foetuses. Lower levels of plasma carotene were found in foetuses from dams with very low plasma carotene levels.

The vitamin $\mathrm{E}$ levels in the foetal plasma were approximately 3.5 times lower than the maternal ones. Similarly, in the newborn children the plasma tocopherol amounted about one fifth of the amount found in their mothers (Wright et al. 1951). This is probably due to limited transplacental transport of vitamin $E$ (Clausen 1971). Significantly lower vitamin E levels were also found by Dvořák (1974) in suckling piglets in the first five days after birth as compared to older animals. Vitamin E concentrations in the plasma of our experimental cows are substantially higher than the tocopherol amount determined by Lyford and Colby (1967), and are in good agreement with the values determined by Samochin et al. (1975) and Dvořák et al. (1977) in winter time.

\section{Hladiny vitamínů $A, E$ a karotenu u vysokobřezích krav a jejich fétů}

$\mathrm{V}$ pokuse na 20 vysokobřezích kravách a jejich fétech ve stáŕi 8 až 9 měsíců byly stanoveny v krevni plazmě koncentrace vitamínu A, E a karotenu. Vitamín A byl rovněž určen $\mathrm{v}$ játrech matek $\mathrm{i}$ fétů.

Hladiny vitamínu A v krevní plazmě fétů byly přibližně 2 krát nižší než v krevní plazmě krav. $V$ játrech fétů byla koncentrace vitamínu $A$ nižší přibližně 10 krát než $\mathrm{v}$ játrech matek.

Při stanovení hladin vitamínu $\mathrm{E}$ a karotenu v krevní plazmě fétů a jejich matek byly tyto hladiny podstatně vyšší u matek. V koncentracích jednotlivých vitamínů mezi krávou a fétem byly rozdily vždy statisticky významné. Fétus a novorozené tele mají nedostatečné zásoby vitamínů a $\mathrm{k}$ jejich zvýšení dochází po přijmu kvalitního kolostra.

Уровни витаминов А, Е и каротина коров в стадии высокой беременности и их зародышей

Определялись концентрации витаминов А, Е и каротина в кровяной плазме коров на высокой стадии беременности и их зародышей в возрасте 8-9 месяцев. В печени был также определен витамин А. Уровни витамина А в кровяной плазме зародышей были по сравнению с кровью коров на более чем 2 раза ниже, в печенке зародышей уровни витамина А были ниже приблизительно в 10 раз. Существенно более высокие уровни витамина Е и каротина были выявлены в кровяной плазме коров по сравнению с зародышами. В сравнении концентраций отдельных уровней витаминов между зародышем и коровой настоящая разница всегда отличалась статистической 
значимостью. Зародыш и новорожденный теленок имеют недостаточные запасы витаминов, которые существенно увеличиваются после своевременной и достаточной подачи качественного молозива.

\section{References}

AMES, S. R.: Factors affecting absorption, transport and storage of vitamin A. Amer. J. Clin. Nutr., 22, 1969: 934-935.

BAETZ, A. L. - HUBBERT, W. T.: Vitamin A in the bovine fetus. Am. J. Vet. Res., 35, 1974: $1189-1190$.

BOUDA, J. - JAGOŠ, P.: Stanovení vitaminů A a E v krevní plazmě, mléku a játrech skotu. Vet. Med. (Praha), 24, 1979, in press.

BRANSTETTER, R. F. et al.: Vitamin A transfer from cows to calves. Nutr. Res., 43, 1973; $142-146$.

CLAUSEN, J.: Vitamin $\mathrm{E}$ in newborn children. In: Vitamin $\mathrm{E}$ in animal nutrition. Anim. Nutr. Events, Roche, Basel, 1972, 82 pp.

DVOŘ́K, M.: Vitamin A a karoten v krevní plazmě sajících telat a jejich závislost na mateřském organismu. Sborník Vysoké školy zemědělské, B, Spisy veterinární fakulty (Brno), 7, 1959: $399-417$.

DVOKÁK, M.: Hypovitaminémie A u chorob sajících telat. Vet. Med., 5, 1960: 521-536.

DVOR̂́K, M.: Levels of vitamin $\mathrm{E}$ in the blood plasma of suckling and weaned piglets. Acta Vet. (Brno), 43, 1974: 103-110.

DVOŘÁ, M. - TOULOVÁ, M. - VOJTÍŠEK, B. - HERZIG, I.: Koncentrace alfatokoferolu a fluorometricky stanoveného vitaminu $\mathrm{E} v$ krevní plazmě krav vysokobřezích a dojících v průběhu odlišných typů krmení. Vet. Med. (Praha), 22, 1977, in press.

EATON, H. D. - ROUSSEAU, J. E. - HALL, R. C.: Reevaluation of the minimum vitamin A requirement of Holstein male calves based upon elevated cerebrospinal fluid pressure. J. dairy Sci., 55, 1972: 232-237.

HARMS, FR.: Vitamin A in Fetus und Jungtier bei Rind und Pferd. Mh. Vet. Med., 6, 1951: $165-169$.

JAGOS, P. - BOUDA, J. - DVOǨAK, V. - HAMŠÍK, V.: Metabolismus a jeho poruchy u telat ve vztahu $\mathrm{k}$ metabolismu vysokobřezich krav. Předneseno na konferenci: Metabolické poruchy vysokoproduktivních dojnic, Smolenice 1.-2. 6. 1977.

JENKINS, K. J. - HIDIROGLOU, M.: A review of selenium, vitamin E responsive problems in livestock: a case for selenium as a feed additive in Canada. Canad. J. Anim. Sci., 52, 1972: $591-620$.

KNOBLOCH, E.: Fyzikálně chemické metody stanovení vitaminů. Praha 1956, 459 pp.

KOVÁČ, G. - VRZGULA, L. - PROSBOVÁ, M.: Vztah tokoferolov k svalovej degenerácii prežúvavcov. Veterinářství, 24, 1974: $551-553$.

KURSA, J.: Nutriční svalová degenerace u mladého skotu v distriktu Sumavy. Vet. Med. (Praha), 14, 1969: 549-559.

LANNEK, N.: The importance of vitamin $\mathrm{E}$ for domestic animals in sickness and in health, Acta Agric. scand., suppl., 19, 1973: 13-21.

LYFORD, S. J. - COLBY, S. E.: Blood tocoferol levels in beef cattle. J. Anim. Sci., 26, 1967: $877-878$.

MOORE, T.: Vitamin A. Amsterdam, Elsevier 1957, 645 pp.

PŘIBYL, E.: Choroby mládat hospodářských zvířat. SZN Praha, 1963, 230 pp.

RADOMINSKI, W. - KONDRACKI, M. - STEFANIAKOWA, B. et al.: Rola niedoboru witaminy A w etiopatogenezie bronchopneumonii cielat. Med. Weter., 26, 1970: 531-534.

RADOSTITS, O. M. - BELL, J. M.: Nutrition of the preruminant dairy calf with special reference to the digestion and absorption of nutrients. Canad. J. Anim. Sci., 50, 1970: 405-452.

ROSENBERGER, G.: Krankheiten des Rindes. Berlin, Hamburg, 1970, 1390 pp.

SAMOCHIN, V. T. et al.: Soderžanie vitaminov v krovi i moloke korov. Veterinarija (Moskva), 9, 1975: 93-95.

SEBRELL, W. H. - HARRIS, R. S.: The vitamins chemistry, Physiology, Pathology, Methods. Second edition, Academic press, New York, London, 1967, 570 pp.

SCHULZ, J. A. - ROSSOW, N.: Lehrbuch der Rinderkrankheiten. Leipzig 1975, 634 pp.

SPIELMANN, A. A. - THOMAS, J. W. - LOOSLI, J. K. - NORTON, C. L. - TURK, K. L.: The placental transmission and fetal storage of vitamin $A$ and caroten in the bovine. J. Dairy Sci., 19, 1946: 707-715.

SPRATLING, F. R. et al.: Experimental hypovitaminosis - A in calves. Clinical and gross post - mortem findings. Vet. Rec., 77, 1965: 1532-1542. 
STEINBACH, G. - EIDNER, M. - MEYER, H.: Zur Auswirkung einer Vitamin A Zufütterung an tragende Muttertiere auf die Gesundheit der Kälber. Monatsh. Vet. Med., 25, 1970: $191-195$.

STEINBACH, G. - MEYER, H.: Zur Bedeutung von Vitamin A und Karotin für das neugeborene Kalb. Arch. Exp. Vet. Med., 21, 1967: 35-41.

THOMPSON, J. N. - ERDODY, P. - BRIEN, R. - MURRAY, T. K.: Fluorometric determination of vitamin $\mathrm{A}$ in human blood and liver. Bioch. Med., 5, 1971: 67-89.

THOMPSON, J. N. - ERDODY, P. - MAXWELL, W. B.: Simultaneous fluorometric determinations of vitamins $A$ and $E$ in human serum and plasma. Bioch. Med., 8, 1873: 403-414.

Van STEVENINCK, J. - De GOEIJ, A. F. P. M.: Determination of vitamin A in blood plasma of patients with carotenaemia. Clinica Chimica Acta, 49, 1973: 61-64.

VRZGULA, L. - AUGUSTINSKÝ, V. - ŠULÍK, F. - DROBCO, J. - CHYLA, M. - KONRÁD, V.: Prvý hromadný výskyt nutričnej svalovej degenerácie u mladého hovädzieho dobytka na Slovensku. Veterináŕství, 22, 1972: 56-60.

WRIGHT, S. W. - FILER, L. J. - MASON, K. E.: Vitamin E Blood levels in premature and full-term infants. Pediatrics, 7, 1951: 386. 